\title{
Effects of effort praise on struggling Filipino ESL readers' motivation and mindset
}

\author{
King Arman Calingasan ${ }^{1}$ and Sterling Miranda Plata ${ }^{2}$ \\ ${ }^{1}$ Department of Professional Education, Notre Dame University, Notre Dame Avenue, Rosary Heights 2, \\ Cotabato City, 9600 Maguindanao, Philippines \\ ${ }^{2}$ Department of English and Applied Linguistics, De La Salle University, 2401Taft Avenue, Malate Manila, 1004 \\ Metro Manila, Philippines
}

\begin{tabular}{|c|c|}
\hline $\begin{array}{l}\text { ABSTRACT } \\
\text { Previous research on praising students to improve their } ~ \\
\text { results. This inconsistency was the impetus for this pape } \\
\text { method experimental design to examine the effects of } \\
\text { mindset of } 60 \text { Filipino seventh-grade students who were } \\
\text { They studied English as a second language (ESL) whe } \\
\text { various texts with appropriate reading styles based on } \\
\text { Department of Education in the Philippines. Using the } \\
\text { 1995), the study found that effort praise led students } \\
\text { growth mindset, while the students in the inverse rul } \\
\text { receiving effort praise. Moreover, although it may inc } \\
\text { effect of effort praise on struggling ESL readers with fi } \\
\text { term. This paper concludes with a schematic diagram to } \\
\text { affects the mindset and the motivation of struggling ESL } \\
\text { practical recommendations to improve reading teachers } \\
\text { specifically effort praise. }\end{array}$ & $\begin{array}{l}\text { on and their mindset had mixed } \\
\text { resent study employed a mixed- } \\
\text { aise on reading motivation and } \\
\text { ized as frustration-level readers. } \\
\text { were expected to comprehend } \\
\text { ade } 7 \text { curriculum guide of the } \\
\text { it Theory Scale (Dweck et al., } \\
\text { ositive rule group to endorse a } \\
\text { adopted a fixed mindset after } \\
\text { eading motivation, the positive } \\
\text { growth mindsets may be short- } \\
\text { e and explain how effort praise } \\
\text { ents in reading. It also provides } \\
\text { ce of giving positive feedback, }\end{array}$ \\
\hline & \\
\hline $\begin{array}{l}\text { First Received: } \\
22 \text { March } 2021 \\
\text { Final Proof Received: } \\
\text { 27 January } 2022 \\
\end{array}$ & $\begin{array}{r}\mathbf{A} \\
22 \mathrm{~J} \\
\text { Published }\end{array}$ \\
\hline \multicolumn{2}{|c|}{$\begin{array}{l}\text { How to cite (in APA style): } \\
\text { Calingasan, K. A. \& Plata, S. M. (2022). Effects of effort praise on struggling Filipino ESL } \\
\text { readers' motivation and mindset. Indonesian Journal of Applied Linguistics, 11(3), 601- } \\
\text { 611. https://doi.org/10.17509/ijal.v11i3.32898 }\end{array}$} \\
\hline
\end{tabular}

\section{INTRODUCTION}

Reading is a skill that plays an important role in personal growth, academic achievement, and civic participation (OECD, 2019). However, reports show a decline in reading motivation among adolescents (Wilkinson et al., 2020), a reading crisis, and an increasing reading gap among this age group (Estremera \& Estremera, 2018; Horowitz, 2017; O'Reilly et al., 2019). According to Fordham (2006), literacy-related issues should be addressed since reading comprehension abilities are critical to the academic achievement of students in junior high school. Adolescents with reading problems meanwhile may struggle with feelings of frustration because of the system of comparison in school and "feeling alienated from teachers" (Triplett, 2004, p. 214). These show the importance of supporting struggling readers and assisting in improving their motivation (Parhiala et al., 2018).

The positive impact of motivation on reading skill development and reading achievement is established in the literature; thus, the challenge for scholars today is to identify approaches that will stimulate motivation among middle school students. One way to achieve this is by praising students' learning efforts. Students have been shown to demonstrate a positive attitude toward task

\footnotetext{
* Corresponding Author

Email: calingasan.kaa@ndu.edu.ph
} 
persistence when they are praised for their effort (Droe, 2012). Effort praise can also result in an increase in student enjoyment and motivation to complete a task and the development of a growth mindset (Mueller \& Dweck, 1998). Since it is motivational, it can also have a positive effect on students' academic performance (Corpus \& Lepper, 2007; Droe, 2012; Mueller \& Dweck, 1998). Effort praise, which can come from teachers (Mueller \& Dweck, 1998) or parents (Gunderson et al., 2013), can help develop a growth mindset. This mindset can positively affect students by instilling in them the belief that their intellectual abilities and personal traits are malleable (Dweck, 2007) and can influence motivation and performance in different subjects such as science (Bedford, 2017; Dai \& Cromley, 2014) and mathematics (Blackwell et al., 2007; Bostwick, et al., 2017; Claro et al., 2016; Jones et al., 2012; Priess-Groben \& Hyde, 2017).

Research also shows that students' belief about the relationship between effort and ability can moderate the effects of effort praise on their motivation and performance in school (Lam et al., 2008, Muenks \& Miele, 2017). They may believe that effort and ability are either positively related (positive rule) or negatively related (inverse rule). In other words, some students might think that people with high ability are the ones who work very hard. They value effort and consider it as an important tool for success. On the one hand, others may think that people with low ability need to work harder than people with high ability to become successful. For example, a student in the frustration-reading level must spend more time and study harder to develop comprehension skills compared with a student in the independent-reading level. Inverse rule meanwhile means that effort is only for students with low ability. When struggling readers believe in the inverse rule, they may feel unmotivated to read because of the mindset that their low ability makes everything extremely difficult.

Despite the number of studies conducted in the area of reading motivation and mindsets, there are still gaps that remain in the field. For example, the tasks in previous studies on the effects of effort praise were not anchored on the curriculum of the subject (Xing et al., 2018). Some researchers conducted their studies in laboratories, which were unrealistic environments (Gunderson et al., 2013) and could have an impact on reliability. Growth mindset studies meanwhile were mostly done in mathematics and science classes, missing the concept's possible application in reading education. In terms of context, most of the data in past investigations came from the United States. In sum, effort praise vis-à-vis reading mindset and motivation in a local setting is a rich area worth exploring since no similar studies have been carried out in the Philippines yet.
The present study aims to fill some of the identified gaps. Specifically, this research attempts to clarify the relationship between beliefs on the effort-ability and motivation of struggling adolescent readers and the effects of effort praise on students' mindset in the L 2 context. This paper also explores the effects of praise on motivation and mindset in reading. To address the ecological issues raised in the literature, the investigation is conducted in a classroom where a teacher provides praise to students and uses materials from the English curriculum of the Department of Education. Finally, this research gathers data from the Philippines which can shed light on cultural differences since most of the studies in this field were done in the United States. It seeks to answer the following research questions:

1. Does effort praise lead the seventh graders to adopt a growth mindset in reading?

2. To what extent will effort praise motivate the seventh graders even after encountering a failure in a reading test?

\section{Mindset}

Based on the Implicit Theories of Intelligence, students with a fixed mindset (i.e., entity theory) are likely to believe that their abilities are stable (Dweck, 1999b), so they do not expend effort to develop them. They perceive that if they have high ability, they do not need to put in much effort to improve (Dweck, 2008). This is the reason why most intelligent students with a fixed mindset worry about proving their ability instead of improving it (Dweck et al., 2014). They also tend to take on a performance goal to validate their ability (Dweck \& Yeager, 2019) and to look smart while doing a task (Dweck, 2008). Fixed-minded students avoid risky tasks because they think that they might be embarrassed especially during setbacks. They often take failure personally and feel ashamed of it (Dweck, 1999a). Moreover, when students experience failures during learning, they easily get unmotivated and give up (Dockterman \& Blackwell, 2014), or they resort to cheating (Blackwell et al., 2007).

In contrast, students who believe that intelligence is malleable prefer a task where they can pursue a learning goal (Mueller \& Dweck, 1998) because they are more interested in discovering new knowledge than minding their ego. This means that despite the challenging task and the possibility of receiving criticism from other people they will still pursue learning. They take calculated risks because they do not fear committing mistakes which, together with effort, are significant elements of learning (Dweck, 2008). If they fail, students with a growth mindset will most likely recover from the setback by utilizing new strategies for learning (Grant \& Dweck, 2003). They view difficult situations as opportunities to put more effort into 
overcoming challenges, which in turn help them improve their abilities, acquire new skills, and extend their mastery. They understand that effort can significantly help them grow their abilities (Dweck, 2007). This growth mindset has resulted in improvements in student's grades and performance in standardized tests (Blackwell et al., 2007; Good et al., 2003).

To put it simply, a growth mindset promotes academic tenacity, whereas a fixed mindset makes students vulnerable to failures (Dweck et al., 2014). In addition, a growth mindset has an important role in inculcating students with perseverance and enthusiasm to learn (Dweck \& Yeager, 2019). It drives them to strive and welcome challenges as avenues in pursuing a learning goal. It also prods students to discover learning strategies that will help them succeed while a fixed mindset leaves them without any strategies to cope with challenges (Dockterman \& Blackwell, 2014) since they view effort negatively and are highly concerned about other people's judgments.

These two types of mindset (i.e., fixed mindset and growth mindset) are closely linked to intrinsic motivation. The former undermines one's intrinsic motivation while the latter enhances this. These mindsets about intelligence are based on the results of a study that distinguished how students with different mindsets responded to success and failure (Dweck et al., 1995). Due to the growth mindset's positive effect on intrinsic motivation, several intervention studies promoting a growth mindset among students were conducted. Some of these interventions were done through pen pal writing (Aronson et al., 2001), mentorship (Good et al., 2003), workshops (Blackwell et al., 2007), and online modules (Paunesku et al., 2015). All these interventions successfully encouraged students of different ages to adopt a growth mindset; as a result, their motivation, as well as their grades, improved.

\section{Reading Motivation}

In reading motivation, students with a fixed mindset can be likened to ambivalent readers and averse readers. Ambivalent readers are students who are intrinsically motivated to read, but their motivation is dependent on the kind of reading text or the reading activity (Guthrie et al., 2009). Similar to students with a fixed mindset, when they perceive that their ability is low, they become less persistent and avoid challenging tasks that produce a negative judgment. A possible factor for reading avoidance is when an activity yields a negative evaluation of their reading competence. Averse readers, meanwhile, have low intrinsic motivation and high reading avoidance. These students intentionally avoid participating in reading activities due to a lack of interest (Guthrie et al., 2009), reflecting a fixed mindset in which students actively oppose challenges.
Avid readers, who have high intrinsic motivation and low reading avoidance, manifest some of the characteristics of students with a growth mindset. They are evidently interested in and enjoy reading and do not avoid reading activities (Guthrie et al., 2009). Moreover, Guthrie and his colleagues found in their study that this group of students has the strongest reading comprehension.

\section{Praise}

Students' mindsets and motivation can be influenced by the type of praise given to them (Dweck, 2007). They usually receive one of the two types of praise after a successful task performance: praise for effort and praise for intelligence or ability. Those who are praised for their effort are more likely to develop and adopt a growth mindset while a fixed mindset will be instilled in those who receive intelligence praise (Dweck, 2007). Additionally, effort praise is more motivational than ability praise since it promotes persistence and enjoyment of the task (Mueller \& Dweck, 1998) and makes students focused on what matters for their motivation and performance (Dweck, 2008). However, Lam et al. (2008) contend that effort praise does not always motivate students, claiming that it can undermine motivation especially if students believe in the inverse rule. Thus, the beliefs about the effort-ability relationship may attenuate the effects of effort praise on motivation.

Drawing from these discussions, it can be theorized that when effort praise is given after a successful reading performance to positive rule students, it will likely stimulate motivation and promote a growth mindset in reading, resulting in improved reading performance. On the other hand, when praised for effort, inverse rule students may become less intrinsically motivated and more avoidant in reading and may develop a fixed mindset, impairing their reading performance.

\section{METHOD \\ Research Design}

This study employed a mixed-method experimental design where qualitative and quantitative data were collected, analyzed, and integrated within the intervention. This design was appropriate in this study because it sought to include the personal experiences of the participants as the qualitative data during the experiment (Creswell \& Creswell, 2018). Moreover, this research intended to receive feedback from the participants after the intervention to explain the effects of the treatment (Sandelowski, 1996). The quantitative part of the study used a quasi-experimental design, specifically a nonequivalent group design where participants were not randomly assigned to conditions (Cook \& Campbell, 1979). A series of assessments were administered during the experimental session to collect data using 
quantitative measures. Quantitative data were analyzed to generate findings concerning the effects of effort praise on students' reading motivation and mindset.

\section{Respondents}

Data for this study came from 60 Filipino grade seven students $($ male $=42$, female $=18$ ) initially classified under the frustration-reading level. They belonged to two classes in a public junior high school in Cotabato City, Philippines. They all had English as a second language (ESL) classes where they were expected to comprehend various texts with appropriate reading styles based on the Grade 7 learning guide of the Department of Education. Grade 7 students were chosen because 1) they deal with challenges and adjustments during this period (Dweck, 2016); 2) it was important for them to develop a growth mindset at this stage to overcome the challenges of high school; 3) students at this age can clearly distinguish the effort from the ability (Nicholls, 1978), and 4) they can understand that effort is commended whey they are praised. In the preliminary data gathering, fifty-five percent of the students believed that effort and ability are positively related (positive rule) while $45 \%$ believed that effort and ability are negatively related (inverse rule).

\section{Instruments}

This investigation utilized scales and tests adapted from sources to measure the non-cognitive domains of the students in reading. Specifically, it used a set of reading tests and surveys to gauge the participants' belief about the effort-ability relationship, reading motivation, and reading mindset. These instruments were pilot tested to ensure reliability. These surveys except the reading tests were translated into Tagalog by a Filipino professor since this is the first language of the participants who had difficulty understanding a statement written in English.

\section{Beliefs about Effort-Ability Relationship}

Students' beliefs about the relationship between effort and ability were measured through a Likert scale formulated by Lam et al. (2008). It was composed of two questions representing types of beliefs about effort-ability relationships. The item that gauged the belief in the positive rule is "If you work very hard, will you become smarter?" It was answered through a 4-point scale ranging from 1 (definitely will not) to 4 (definitely will). The second item reflected the inverse rule: "If you work very hard and then receive a good result, how much does this indicate that you are smart?" The participants responded to a 4-point scale ranging from 1 (very smart) to 4 (not very smart). The 2 item scale that was used to determine the effortability relationship beliefs of the students was highly reliable with a Cronbach alpha coefficient reported of .84.

The interpretation of beliefs about the effortability relationship was based on the study of Lam et al. (2008). A higher rating in the first item was interpreted as higher agreement to smartness and greater endorsement of the positive rule while a higher rating in the second was interpreted as lower agreement to smartness and greater endorsement of the inverse rule. To determine the overall beliefs of the students in the effort-ability relationship, the score in the second item was subtracted from the score in the first item. If the result was positive, it indicated the endorsement of the positive rule. If the result was negative, it indicated the endorsement of the inverse rule.

\section{Reading Comprehension Tests}

Since the participants were readers at frustration level, two reading comprehension tests for Grade 4 to ensure they were easy and one from Grade 7 for the difficult test were utilized. The texts and comprehension questions, lifted from the recommended screening test in the Phil-IRI manual, were required to be read and answered within five minutes.

The first reading test, which used the 67 -word The Best Part of the Day, was easy, so students had a high probability of getting a passing grade. To investigate whether they would persist to take another test despite the failure and to validate the argument that effort praise has limited benefits when hard work results in a failure (Xing et al., 2018), the second reading test was designed to be difficult. It was taken from a seventh-grade reading passage, Telling Time, with 134 words. Finally, the last reading test, which used the 65-word Ice Cream for Sale, was as easy as the first test.

\section{Implicit Theory Scale}

Students' mindset was assessed through the Implicit Theory Scale (ITS) which was considered reliable because of its high internal reliability ( $\alpha$ ranged from .94 to .98 ) and a .80 test-retest reliability over a 2-week interval (Dweck et al., 1995). In the present study, the Cronbach alpha of the ITS was .7 which had a good internal consistency. It is a 6point scale from 1 (strongly agree) to 6 (strongly disagree) which consists of three statements. In this research, the word intelligence in statements from the original instrument was changed to reading ability. In the test, students' mindset is considered fixed if they score 3.0 or below while students are classified with a growth mindset if they earn an overall score of 4.0 or above (Dweck et al., 1995).

\section{Reading Motivation Survey}

An adapted scale from experimental studies (Mueller \& Dweck, 1998) was used to survey the intrinsic motivation (i.e., persistence and enjoyment) 
of the participants. Students' responses were scaled from 1 (not at all) to 4 (very much). Originally, there were two constructs included in the previous survey, but the current study added one construct based on Guthrie et al.'s (2009) reading motivation scale. The third construct was coded inversely to determine the overall reading motivation of the students after receiving effort praise. This survey had an overall satisfactory internal consistency $(\alpha=$ .74).

\section{Interview questions}

Semi-structured interview questions were asked to investigate further the impact of teacher's effort praise on a student's mindset and motivation in reading. Students answered nine questions that were anchored on the theories of effort praise, mindset, and reading motivation. The questions were ensured to be clear, so participants could respond to them. All questions were validated by an expert researcher and translated into Tagalog for better comprehension during the interview.

\section{Procedures}

The permission of the school division superintendent of Cotabato City, Philippines and subsequently of the principal of the school was secured first. After, the students were given an informed consent form with the parent's approval to secure their participation in the study.

A Filipino ESL teacher from the public junior high school was invited to carry out the research procedure in the pilot study. She was trained to administer all the instruments prior to the actual data gathering. The rationale of the study was explained to her, and a script, containing procedures and the statements, was provided.

The first part of the data collection was done in an English class where the participating teacher asked the students to answer the two questions that measured their beliefs about the relationship between effort and ability. The results were used to group students into two according to their effort beliefs: positive rule or inverse rule. It took them three minutes to finish the survey. After that, they continued with their lesson in English reading.

On the second day, the participating teacher started class with a review of the lesson. After the five-minute review, the students were instructed to complete a set of reading tests as part of their assessment. They were given three answer sheets and a score sheet. They were required to finish the first reading test within five minutes. After completing it, the teacher collected their answer sheets and gave them to the researcher who stayed at the back of the classroom. While the teacher was explaining the answers in the first test, the researcher pretended to check their answers and gave them back immediately to the teacher after a short discussion. The teacher called the students one at a time to give the result of the test without showing them the answer sheets. The students were not aware that the scores written on their score sheets were not true. They were given higher points than their real score on purpose so that the teacher could articulate the effort praise to the students. She praised them orally and individually with a smile to show sincerity by saying, "You got a high score. You must have worked hard on this reading test."

After giving the scores to the students and verbally praising their efforts in reading, the teacher asked them to answer a short survey on the reading mindset. When all of them were done, they proceeded to the second reading test and applied the same procedures in the first test. However, since the second test was difficult for students at the frustration reading level, they were told that they got low scores. Next, students were asked to evaluate their persistence on the reading test, their enjoyment of answering the reading test, and their desire to avoid the reading test by completing the reading motivation survey. Finally, the students answered the third reading test which was easier than the second test. No more feedback about their score was given this time.

After the final test, sixteen randomly selected students were interviewed individually by the researcher regarding their experiences in the reading tests and in reading in general. Debriefing was done after the students completed all the assessments. The teacher also reminded them not to share their experiences with others after the experimental session to ensure the authenticity and validity of responses of other participants for the subsequent study.

\section{FINDINGS AND DISCUSSION \\ Effects of Effort Praise on Reading Mindset}

Table 1 reports the effects of effort praise on the reading mindset of the participating students. The results indicate that effort praise led the students in the positive rule group to adopt a growth mindset in reading $(M=3.52, S D=1.44)$. In other words, effort praise seems to instill a belief that reading abilities are malleable for students who positively view the relationship between effort and ability. Students in the positive rule believe that effort correlates with high ability. For them, the more they exert effort, the more they improve their ability. Similarly, students with a growth mindset give high regard to the effort since they believe that intellectual abilities can be enhanced over time by working hard (Dweck $\&$ Yeager, 2019). Therefore, students who have a positive belief in effort-ability relationships will more likely appreciate effort praise because they consider hard work as an important aspect in developing their abilities.

In this study, fifty-eight percent of the students in the positive rule group manifested a growth mindset in reading after receiving effort praise, 
suggesting that effort praise can be an effective strategy to develop a growth reading mindset to the students in the frustration reading level. This finding supports the assertion that students praised for their effort tend to develop a growth mindset than those praised for their intelligence (Dweck, 2007; Mueller \& Dweck, 1998) and that this mindset can assist in molding children's motivational frameworks in cognitive and sociomoral domains.

Table 1

Means and Standard Deviations on the Reading Mindset

\begin{tabular}{lccc}
\hline & & \multicolumn{2}{c}{ Reading Mindset Score } \\
\cline { 3 - 4 } EAR Beliefs Group & $\boldsymbol{N}$ & $\boldsymbol{M}$ & $\boldsymbol{S D}$ \\
\hline Inverse Rule & 27 & 2.22 & .69 \\
Positive Rule & 33 & 3.52 & 1.44 \\
\hline
\end{tabular}

Note. Fixed Mindset $=3.4$ and below; Growth Mindset $=$ 3.5 and above. EAR = Effort-Ability Relationship

Although the current study confirms that effort praise can influence students to adopt a growth mindset, it argues that this can be made possible when they have a positive belief in effort-ability relationships. As observed in this study, when students, who negatively viewed this relationship, received effort praise from the teacher after a successful reading performance, they tended to espouse a fixed mindset in reading $(M=2.22, S D=$ .69). This suggests that, while they believed that effort was inversely related to low ability, they perceived that their reading abilities could no longer be enhanced even if they exerted extra effort. This is supported by studies that hypothesized that people with a fixed mindset will see effort as inversely related to ability across contexts (Muenks \& Miele, 2017). If students with a fixed mindset are asked to exert effort to accomplish a task, they perceive that they lack ability even if they succeed (Dweck, 1999b). That is why inverse rule students in this study endorsed a fixed mindset even after receiving effort praise as they negatively perceived the relationship of effort and ability.

In a follow-up interview, inverse rule students showed some characteristics of a fixed mindset. A majority of them preferred a shorter text, so they could easily answer the questions. Aside from that, they reasoned they wanted to read shorter texts to avoid making mistakes, to prevent difficulty in reading, and to avoid tiredness. This preference is a characteristic of a fixed mindset since students who believe that their intellectual abilities are stable tend to avoid taking risks for fear of being embarrassed by setbacks. They often take failure personally and feel ashamed of it (Dweck, 1999a). In the current study, it can be assumed that inverse group students might think that their low reading abilities were fixed, so they opted to read a shorter text to be safe from possible failures. This preference for shorter texts is demonstrated by this exchange from one interview. English translations are provided in parentheses.

Researcher: Okay ahh... anong gusto mong teksto na basahin? maikli ah o mahabang teksto? (Okay ahh. What type of text do you prefer to read? Long or short text?)

Student I: Hmm. Maikli po. (Hmm. Short text, Sir)

Researcher: Bakit maikli? (Why?)

Student I: Kasi po madali ko lang po maintindihan (Because I can easily understand it.)

(Personal Interview I, Inverse Rule Group)

In contrast to those in the inverse rule group, positive rule students, who developed a growth mindset after receiving effort praise, preferred long and difficult texts to extend their learning. Some of them mentioned that reading long texts could enhance their reading skills, widen their knowledge in English, and help them get used to reading challenging texts. This finding is aligned with that of Dweck (2007). She reported that students with a growth mindset perceive difficult situations as opportunities to exert effort to overcome challenges, which in turn help them improve their abilities and acquire new skills. These students understand that effort can significantly help them grow their abilities (Dweck, 2007). As a result, effort praise successfully conveyed a message that hard work is important to develop their reading abilities.

With these findings, it can be deduced that effort praise could be effective in stimulating a growth mindset in reading among students who hold a positive belief in effort-ability relationships. However, it seems that it does not always promote a growth mindset to students in general contrary to the findings of Dweck (2008). The effectiveness of effort praise in inculcating a growth mindset in reading into students could be attenuated by their negative beliefs in effort-ability relationships. Effort praise might mean that they need to work harder because of low innate ability (Amemiya \& Wang, 2018). Thus, students at the frustration-reading level were more likely to believe that their reading abilities were inherently fixed after being praised for their effort.

\section{Effects of Effort Praise on Reading Motivation}

After encountering a failure in the second reading test, both inverse rule students $(M=2.94, S D=.52)$ and positive rule students $(M=3.34, S D=.32)$ who received effort praise from their teachers became slightly motivated to pursue another reading test (see Table 2). This means that regardless of their belief in the relationship of effort and ability, praising them for their effort in reading may neither make them less motivated or highly motivated especially amid setbacks.

To some extent, the present findings do not affirm the claim that effort praise can undermine motivation especially if students believe in the inverse rule (Lam et al., 2008). 
Table 2

Means and Standard Deviations on the Reading Motivation

\begin{tabular}{llll}
\hline & & \multicolumn{2}{l}{ Reading Motivation Score } \\
\cline { 3 - 4 } EAR Beliefs Group & $\boldsymbol{N}$ & $\boldsymbol{M}$ & $\boldsymbol{S} \boldsymbol{D}$ \\
\hline Inverse & 27 & 2.94 & 0.52 \\
Positive & 33 & 3.14 & 0.47 \\
\hline Note. & $1.00-1.49=$ A little, & $1.50-2.49=$ Not at All, $2.50-$ \\
& $3.49=$ Slightly, & $3.50-4.00=$ Very & Much
\end{tabular}

In this study, the use of effort praise was found comparatively effective in motivating students including those who had an inverse belief of effortability relationship. In fact, this type of praise elicited positive emotions among students in both groups. A majority of them initially felt happy, inspired, and confident after hearing praise from their teacher. It was also surprising that no negative emotions were associated with effort praise by the students as shown by this interview extract:

Researcher: Ano yung nararamdaman mo nung sinabi sayo ni ma'am Irish na talagang pinagsikapan mo daw yung unang test? (What did you feel when teacher Irish complimented your effort during your first test?)

Student A: Sobrang saya po para sa akin. (It brings so much happiness to me.)

Researcher: Bakit? (Why?)

Student A: Kasi parang kasi parang proud po ako kasi pinaghirapan ko po talaga yun. (It made me proud of myself since I really strived hard for it.)

(Personal Interview A, Positive Rule Group)

Moreover, some students who struggled in reading expressed their desire to hear this type of praise since it could boost their confidence in reading especially challenging texts with difficult words. It shows that effort praise can persuade students to persist despite having trouble in reading a text.

Student G: Gusto ko pong marinig yun para sir madagdagan pa po yung lakas ng loob ko na mag basa ng mahirap na salita po sir. (I want to receive that kind of praise (effort praise) to gain more confidence in reading difficult words.)

(Personal Interview G, Positive Rule Group)

Previous studies confirmed that effort praise had a positive influence on the task persistence of students. For example, a series of studies revealed that effort praise significantly increased the task persistence of the seventh graders (Mueller \& Dweck, 1998). Similarly, Droe (2012) found that students' task persistence improved in completing all the pairs in rhythm sets due to the effort praise that was given to them.

Nonetheless, effort praise has its downsides in motivation. Although it was observed in this study that the student beliefs on effort and ability relationship did not moderate the effects of effort praise on motivation, contrary to findings of Lam et al. (2008), effort praise may backfire due to prior setbacks experienced by the students in reading. For example, most of the students in both groups conveyed negative emotions after receiving a failing mark in the second test. They felt disheartened and hurt because of the undesirable outcomes of their reading performance. In addition, some of the inverse rule students began to doubt their reading abilities because of the failure. Student $\mathrm{H}$ said, "It hurts because I failed, Sir." A similar feeling was expressed by Student $\mathrm{O}$ during the interview, "I slightly feel that I'm not that good at reading every time I fail."

Effort praise might have limited benefits if hard work resulted in failure (Xing et al., 2018). Although it may motivate students to some certain extent, it gradually diminishes the level of their motivation when confronted with difficulty. In addition, effort praise may be interpreted by adolescents as an indication of a lack of ability (Amemiya \& Wang, 2018) as this often happens among students who experienced being stigmatized for having a low ability. In relation to reading, students at the frustration-reading level often perceive themselves as unsuccessful readers (McLaughlin \& Rasinski, 2015) and usually lose enjoyment in reading and associate it with awful experiences (Padak \& Potenza-Radis, 2010). Hence, when effort praise is given to them for doing well in a task, they react negatively because they remember their previous or present failures.

In this study, the students in both groups initially expressed positive emotions on motivation after receiving effort praise. However, it had a fleeting positive effect on their reading motivation when difficulty arose. When students were asked how they felt about their performance in the more challenging reading test, none of them provided an optimistic response, suggesting that effort praise may weaken the reading motivation of students, especially those at the frustration level, if their work results in a failure.

To illustrate the results of the two research questions, this study presents a schematic diagram that explains how effort praise affects the reading mindset and reading motivation of the students with different effort-ability relationship beliefs (Figure 1). Effort praise can help positive rule students at frustration-reading level develop a growth mindset or the belief that reading abilities are malleable. If this is the case, then one can surmise that effort praise can be an effective strategy in stimulating a growth mindset in reading among students with difficulties in reading comprehension (Dweck, 2007). 
Figure 1

A Schematic Diagram of the Effects of Effort Praise on Mindset and Motivation in Reading

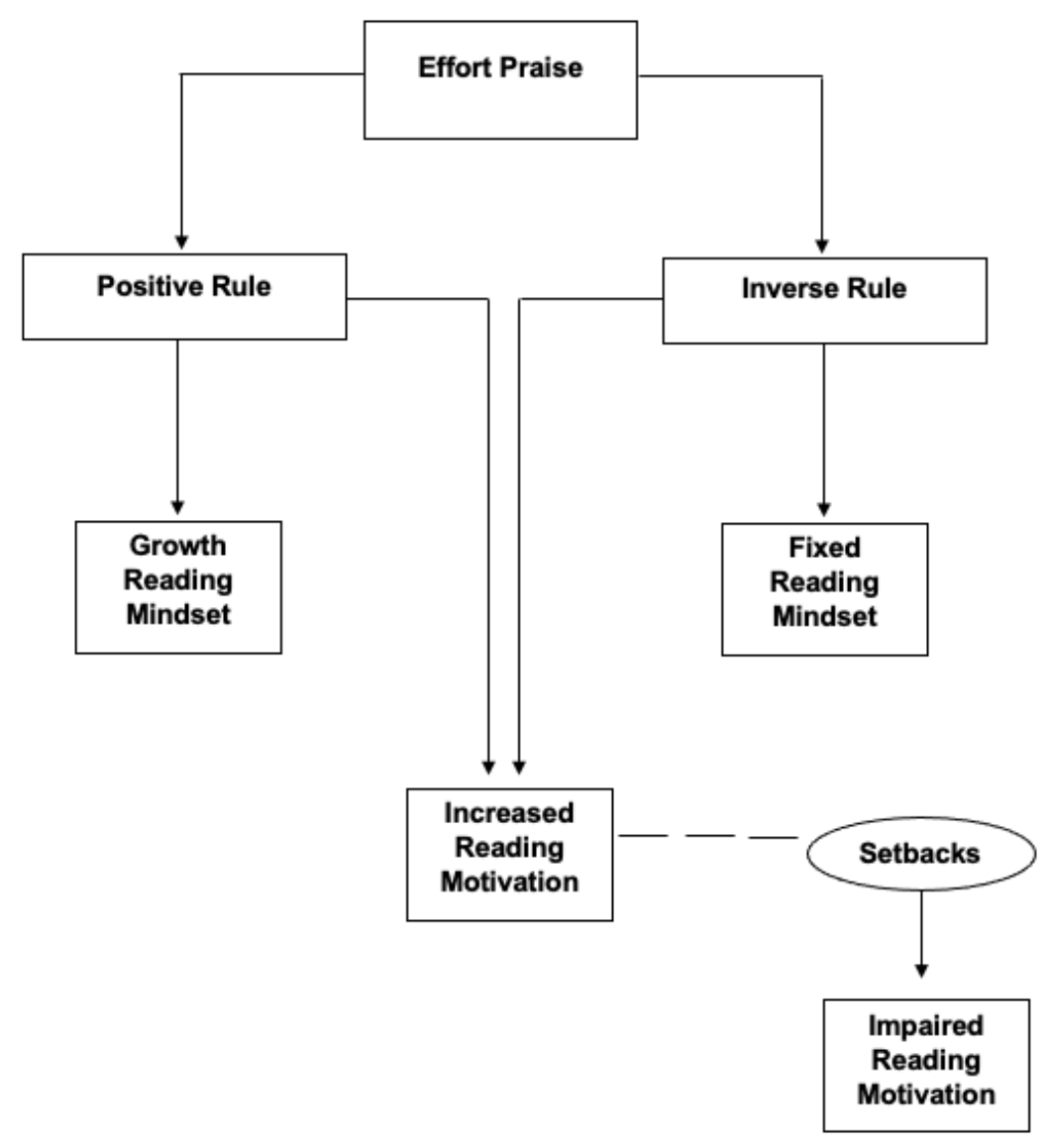

Nevertheless, effort praise can be detrimental because it can lead students to think that they must exert effort due to their low inherent ability (Amemiya \& Wang, 2018). Participants in the study developed a fixed mindset after receiving effort praise, showing that its impact on developing a growth mindset is mitigated by negative beliefs in effort-ability relationships. Effort praise might also have a limited impact on improving performance if received by inverse rule students with a fixed mindset. In fact, the data of the study showed that it can even impair the performance of students who saw their abilities as stable as they got easily demotivated and gave up on their tasks (Dockterman $\&$ Blackwell, 2014). Students might opt not to exert effort to enhance their reading skills, which could result in poor performance.

This study likewise found that students who received effort praise became slightly motivated to read another text, but this effect might not transpire if students negatively interpret it by thinking that effort and ability were inversely related (Lam et al., 2008). Although it may increase motivation, the positive effect of effort praise on L2 struggling readers may be short-term. The data also showed that effort praise may elicit positive emotions, but students will feel disheartened when faced with reading challenges or setbacks (Xing et al., 2018). Thus, regardless of students' belief in the relationship of effort and ability, praising the struggling readers for their effort in reading may not be able to sustain their motivation in reading when the text or reading activity becomes difficult.

\section{CONCLUSION}

This present study examined the effects of effort praise on the mindset and the reading motivation of Filipino ESL struggling readers. However, unlike past studies, this research considered the beliefs of students on effort-ability relationships that shed light on the inconsistencies of the previous researchers' arguments regarding the effectiveness of effort praise. The novel findings revealed by this research may inform ESL teachers on the proper administration of effort praise to students after a successful performance in reading.

In this study, effort praise affects the mindset of the students at the frustration reading level who have different effort-ability relationship beliefs. For students who believed that high effort correlates with high ability, effort praise may lead them to 
adopt a growth mindset in reading. In other words, when they received an effort praise, they began to think that their reading abilities are malleable and can be developed through effort. Moreover, the students in the positive rule group manifested some characteristics of a person who endorses a growth mindset. For example, the majority of them preferred long and difficult texts to extend their learning. Some of the students also mentioned that reading long texts can improve their reading skills, widen their knowledge in English, and help them get used to reading challenging texts.

However, effort praise may have a negative effect on the mindset of the students who believed that effort and ability are negatively related. This type of praise can influence the students in the inverse rule group to view their reading abilities as fixed entities. Additionally, students in the frustration reading level were more likely to believe that their reading abilities are inherently fixed after being praised for their effort. This finding was supported by their responses to the interview. Most of them preferred a shorter text to answer the questions easily after the reading text. Aside from that, they reasoned out that they wanted to read short texts to avoid making mistakes or encounter difficulty in reading, and not to get tired easily. Students in the inverse rule group, who received an effort praise, began to think that their low reading abilities were fixed, so they opted to read a shorter text to be safe from possible failures.

In addition, the findings of this study revealed that effort praise slightly motivated the students in both groups after encountering a failure in the second reading test. To substantiate this finding, the qualitative data indicated that students who were praised for their effort initially felt happy, inspired and confident. Moreover, some students who struggled in reading expressed their desire to hear this type of praise since it can boost their confidence in reading, specifically comprehending challenging texts with difficult words. It implies that effort praise can also persuade students to persist despite having trouble in reading a text. Although it was motivational to some extent, effort praise had a fleeting effect on reading motivation. Students in the frustration reading level were easily affected by setbacks in reading. Regardless of their beliefs in effort-ability relationship, most of them conveyed negative emotions after receiving a failing mark in the second test. They felt disheartened and began to doubt their reading abilities because of the undesirable outcomes of their reading performance.

Based on the findings, this study recommends that ESL teachers ensure that the student learning environment is free from the competition (Nicholls, 1984) to enable them to shift from inverse rule to positive rule because the environment plays a crucial role in this (Muenks \& Miele, 2017). Instead, it is best to place students in a task-involved situation where they can concentrate on their personal growth and development of their competence and which encourages them to judge ability similar to skills that can be enhanced over time through hard work (Muenks \& Miele, 2017). Teachers should also aim to develop students' growth mindset which is shown to result in better academic performance (Mueller \& Dweck, 1998), to promote academic tenacity (Dweck et al., 2014), to develop learning strategies (Dockterman \& Blackwell, 2014), and to enhance their resilience in the face of difficulties. One way to promote a growth mindset is to use effort praise to students, including those who are struggling. Teachers should regularly praise the efforts of their students as this can eventually lead to better reading skills. Educators should likewise emphasize effort in teaching reading by following a more processoriented approach to teaching where skills are given prominence. The effort of students in reading should also be considered in assessing their reading skills since this will demonstrate the value of hard work. This will also minimize students' guessing of answers and provide teachers an idea of the thinking process behind their answers. Finally, teachers should properly process the setbacks students experience and explain that these are part of learning to avoid demotivation on the part of learners. They can also use process-focused criticism (Dweck, 2008) to make them understand how to do better in reading next time.

\section{REFERENCES}

Amemiya, J., \& Wang, M. (2018). Why effort praise can backfire in adolescence. Child Development Perspectives, 12(3), 199-203. https://doi.10.1111/cdep.12284

Aronson, J., Fried, C., \& Good, C. (2001). Reducing the effects of stereotype threat on African American college students by shaping theories of intelligence. Journal of Experimental Social Psychology, 38(2), 113-125. https://doi.org/10.1006/jesp.2001.1491

Bedford, S. (2017). Growth mindset and motivation: A study into secondary school science learning. Research Papers in Education, 32(4), 424-443. https://doi.org/10.1080/02671522.2017.131880 9

Blackwell, L. S., Trzesniewski, K. H., \& Dweck, C. S. (2007). Implicit theories of intelligence predict achievement across an adolescent transition: A longitudinal study and an intervention. Child Development, 78(1), 246263. https://doi.10.1111/j.14678624.2007.00995.x

Bostwick, K., Collie, R., Martin, A., \& Durksen, T. (2017). Students' growth mindsets, goals, and academic outcomes in mathematics. Zeitschrift 
Psychol, 225(2), 107-116.

https://doi.10.1027/2151-2604/a000287

Claro, S., Paunesku, D., \& Dweck, C. S. (2016). Growth mindset tempers the effects of poverty on academic achievement. Proceedings of the National Academy of Sciences U.S.A, 113(31), 8664-8668. https://doi.10.1073/pnas.1608207113

Corpus, J. H., \& Lepper, M. R. (2007). The effects of person versus performance praise on children's motivation: Gender and age as moderating factors. Educational Psychology, 27(4), 487-508. https://doi.10.1080/01443410601159852.

Cook, T. D., \& Campbell, D. T. (1979). Quasiexperimentation: Design \& analysis issues in field settings. Houghton Mifflin.

Creswell, J. W., \& Creswell, J. D. (2018). Research design: Qualitative, quantitative, and mixed methods approaches ( $5^{\text {th }}$ ed.). SAGE.

Dai, T., \& Cromley, J. G. (2014). Changes in implicit theories of ability in biology and dropout from STEM majors: A latent growth curve approach. Contemporary Education Psychology, 39(3), 233-247. https://doi.10.1016/j.cedpsych.2014.06.003

Dockterman, D., \& Blackwell, L. (2014). Growth mindset in context: Content and culture matter too. International Center for Leadership in Education.

Droe, K. (2012). Effect of verbal praise on achievement goal orientation, motivation, and performance attribution. Journal of Music Teacher Education, 23(1), 63-78. https://doi.org/10.1177/1057083712458592

Dweck, C. S. (1999a). Caution: Praise can be dangerous. American Educator, 23(1), 4-9.

Dweck, C. S. (1999b). Self-Theories: Their role in motivation, personality, and development. Psychology Press.

Dweck, C. S. (2007). The perils and promises of praise. Educational Leadership, 65(2), 34-39.

Dweck, C. S. (2008). Mindsets: How praise is harming youth and what can be done about it. School Library Media Activities, 24, 55-58.

Dweck, C. S. (2016). Mindset: The new psychology of success (Rev. ed.). Ballantine Books.

Dweck, C. S., Chiu, C., \& Hong, Y. (1995). Implicit theories: Elaboration and extension of the model. Psychological Inquiry, 6(4), 322-333. https://doi.10.1207/s15327965pli0604_12

Dweck, C. S., Walton, G. W., \& Cohen, G. L. (2014). Academic tenacity: Mindsets and skills that promote long-term learning. Bill and Melinda Gates Foundation.

Dweck, C. S., \& Yeager, D. S. (2019). Mindsets: A view from two eras. Perspectives on Psychological Science, 14(3), 1-16. https://doi.org/10.1177/1745691618804166
Estremera, M. L., \& Estremera, G. L. (2018). Factors affecting the reading comprehension of grade six pupils in the city division of Sorsogon, Philippines as the basis for the development of the instructional model. Asia Pacific Journal of Education, Arts and Sciences, 5(3), 72-78.

Fordham, N. W. (2006). Crafting questions that address comprehension strategies in content reading. Journal of Adolescent and Adult Literacy, 49(5), 390-396. https://doi.org/10.1598/JAAL.49.5.3

Good, C., Aronson, J., \& Inzlicht, M. (2003). Improving adolescents' standardized test performance: An intervention to reduce the effects of stereotype threat. Journal of Applied Developmental Psychology, 24(6), 645-662. https://doi.org/10.1016/j.appdev.2003.09.002

Grant, H., \& Dweck, C. S. (2003). Clarifying achievement goals and their impact. Journal of Personality and Social Psychology, 85(3), 541553. https://doi.org/10.1037/00223514.85.3.541

Gunderson, E. A., Gripshover, S. J., Romero, C., Dweck, C. S., Meadow, S. G., \& Levine. S.C. (2013). Parent praise to 1-3-year-olds predicts children's motivational frameworks 5 years later. Child Development, 84(50), 1526-1541. https://doi.10.1111/cdev.12064

Guthrie, J. T., Coddington, C. S., \& Wigfield, A. (2009). Profiles of reading motivation among African and American students. Journal of Literacy Research, 41(3), 317-353. https://doi.org/10.1080/10862960903129196

Horowitz, R. (2017). International brain wars: Adolescent reading proficiency, performance, and achievement from a competitive global perspective. In R. Horowitz \& S. Jay Samuels (Eds.), The achievement gap in reading (pp. 123-148). Routledge.

Jones, B., Wilkins, J., Long, M., \& Wang, F. (2012). Testing a motivational model of achievement: How students' mathematical beliefs and interests are related to their achievement. European Journal of Psychology of Education, 27(1), 1-20. https://doi.org/10.1007/s10212011-0062-9

Lam, S., Yim, P., \& Ng, Y. (2008). Is effort praise motivational? The role of beliefs in the effortability relationship. Contemporary Educational Psychology, 33(4), 694-710. https://doi.org/10.1016/j.cedpsych.2008.01.005

McLaughlin, M., \& Rasinski, T. V. (2015). Struggling readers: Engaging and teaching in grades 3-8. International Literacy Association.

Mueller, C. M., \& Dweck, C. S. (1998). Praise for intelligence can undermine children's motivation and performance. Journal of Personality and Social Psychology, 75(1), 3352. https://doi.org/10.1037//0022-3514.75.1.33 
Muenks, K., \& Miele, D. B. (2017). Students' thinking about effort and ability: The role of developmental, contextual, and individual difference factors. Review of Educational Research, 87(4), 707-735. https://doi.10.3102/0034654316689328.

Nicholls, J. G. (1978). The development of the concepts of effort and ability, perception of academic attainment, and the understanding that difficult tasks require more ability. Child Development, 49(3), 800-814. https://doi.10.2307/1128250.

Nicholls, J. G. (1984). Achievement motivation: Conceptions of ability, subjective experience, task choice, and performance. Psychological Review, 91(3), 328-346. https://doi.10.1037/0033295X.91.3.328

OECD (2019), PISA 2018 assessment and analytical framework. OECD Publishing. https://doi.org/10.1787/b25efab8-en

O'Reilly, T., Sands, A., Wang, Z., Dreier, K., \& Sabatini, J. (2019). Curbing America's reading crisis: A call to action for our children. Policy report. ETS Center for Research on Human Capital and Education, 1-32.

Padak, N., \& Potenza-Radis, C. (2010). Motivating struggling readers: Three keys to success. New England Reading Association Journal, 45(2), 1-7.

Parhiala, P., Torppa, M., Vasalampi, K., Eklund, K., Poikkeus, A. M., \& Aro, T. (2018). Profiles of school motivation and emotional well-being among adolescents: Associations with math and reading performance. Learning and Individual Differences, 61, 196-204. https://doi.org/10.1016/j.lindif.2017.12.003
Paunesku, D., Walton, G. M., Romero, C., Smith, E. N., Yeager, D. S., \& Dweck, C. S. (2015). Mind-set interventions are a scalable treatment for academic underachievement. Psychological Science, 26(6), 784-793. https://doi.org/10.1177/0956797615571017

Priess-Groben, H., \& Hyde, J. (2017). Implicit theories, expectancies, and values predict mathematics motivation and behavior across high school and college. Journal for Youth Adolescence, 46(6), 1318-1332. https://doi.10.1007/s10964-016-0579-

Sandelowski, M. (1996). Using qualitative methods in intervention studies. Research in Nursing \& Health, 19(4), 359-364. https://doi.org/10.1002/(SICI)1098240X(199608)19:4<359::AIDNUR9>3.0.CO;2-H

Triplett, C. F. (2004). Looking for a struggle: Exploring the emotions of a middle school reader. Journal of Adolescent and Adult Literacy, 48(3), 214-222. https://doi.org/10.1598/JAAL.48.3.3

Wilkinson, K., Andries, V., Howarth, D., Bonsall, J., Sabeti, S., \& McGeown, S. (2020). Reading during adolescence: Why adolescents choose (or do not choose) books. Journal of Adolescent \& Adult Literacy, 64(2), 157-166. https://doi.org/10.1002/jaal.1065

Xing, S., Gao, X., Jiang, Y., Archer, M., \& Liu, X. (2018). Effects of ability and effort praise on children's failure attribution, selfhandicapping, and performance. Frontiers in Psychology, 9, 1883. https://doi.10.3389/fpsyg.2018.01883 